\title{
Effect of garlic powder on performance and lipid profile of broilers
}

\author{
Kamal Jamal Issa ${ }^{1}$, J. M. Abo Omar ${ }^{2^{\star}}$ \\ ${ }^{1}$ Palestine Poultry Company, Tulkarm, Palestine \\ ${ }^{2}$ Department of Animal Production, An Najah National University, Nablus, Palestine; \\ *Corresponding Author: aboomar57@,najah.edu
}

Received 29 October 2011; revised 21 December 2011; accepted 31 December 2011

\section{ABSTRACT}

This experiment was conducted to investigate the effect of feeding garlic powder (GP) on the performance, digestibility, digestive organs, carcass cuts and lipid profile of broilers. A total of 270 day-old Cobb-500 chicks were used in the experiment. Birds were partitioned into three experimental groups of 90 birds in each. Each treatment was composed of 6 replicates with 15 birds in each. The control group was fed with a commercial starter and finisher diet. The second and third groups were supplemented with GP at the rate of $0.2 \%$ and $0.4 \%$ respectively. In the last week of experiment, 18 birds from each experimental group ( 3 birds per replicate) were used in a metabolic trial. At the time of termination of the experiment, the same number of birds were killed for digestive organs and carcass components measurements. Blood samples from 3 birds per replicate were collected on $3^{\text {rd }}, 5^{\text {th }}$ and $6^{\text {th }}$ week post feeding from wing vein for blood lipid profile determination. Total cholesterol (COL), triglycerides (TG), high density lipoprotein (HDL), low density lipoprotein (LDL) levels were determined. Results of this study showed that GP had no significant effects on broilers weight gain, feed intake (FI), feed conversion ratio (FCR), carcass cuts, visceral organs. However, GP decreased $(P<0.05)$ COL, TG, LDL and increased HDL levels compared to control birds. The dry matter (DM), crude protein (CP) and ether extract (EE) digestibility were improved by feeding GP. It can be concluded that GP could provide positive advantages in broilers performance.

Keywords: Garlic Powder; Broilers; Lipids;

Performance; Digestive Organs

\section{INTRODUCTION}

The use of antibiotics as growth promoters is facing serious criticism [1]. There are some important reasons that restrict the use of antibiotics such as the drug resistance in bacteria and the drug residues in meat [2]. To overcome the poor performance and the increase susceptibility to diseases resulted from removal of antibiotics from birds diets, attempts were made to find other alternatives. The utilization of growth promoters of natural origin become of an interest in recent years [1]. Garlic (Allium sativum) has bioactive components like sulfur containing compounds (Alliin, Diallylsulfides and Allicin) that act as antibacterial, antifungal, anti parasite, antiviral, antioxidant, antithrombotic, ant cancerous and vasodilator characteristics.

Garlic has been found to lower serum and liver cholesterol [3], inhibit bacterial growth [4], inhibit platelet growth and reduce oxidative stress. In broilers, it was reported that garlic, as a natural feed additive, improved broiler growth and feed conversion ratio (FCR), and decreased mortality rate [5].

Improvement of broilers performance and carcass merits can be achieved by supplementation of diets with GP [6-9]. It was reported that feeding GP at levels of 1.5, 3 and $4.5 \%$ had no effect on birds performance [10], but caused a significant reduction in birds serum and liver cholesterol. However, Horton et al. (1991) [11] concluded that triglyceride was not affected by garlic in broiler chickens. Serum cholesterol was decreased with feeding garlic to layers $[7,12]$ showed that addition of plant extracts to broilers' diet has some effects on performance and microbial activity of intestinal tract but, none of them were significant. Using GP in broilers' diet had no significant effect on performance but it influenced meat quality and carcass yield positively [11]. However, garlic effects on broilers performance, carcass characteristics and blood lipids are debatable.

The objective of this study was to investigate the effect of feeding GP on performance, digestibility, blood 
lipid profile, digestive organs and carcass cuts of broiler chickens.

\section{MATERIALS AND METHODS}

The experimental protocol describing the management and care of birds was reviewed and approved by the Animal Care and Use Committee of An Najah National University.

\subsection{Experimental Design, Birds, Housing and Diets}

A total 270 of one day-old broiler chicks (Cobb 500) purchased from a local hatchery (Poultry Company of Palestine, Tulkarm, Palestine) were used in a 6-week trial. Dietary treatments included: C (control diet, $0 \mathrm{GP}$ ); $0.2 \%$ GP and $0.4 \%$ GP. Chicks were randomly allotted to a 3 treatments (6 replicates with 15 birds per replicate). Birds were subjected to a 2-period feeding program consisting of a starter ( 0 to 3 weeks) and finisher (3 to 6 weeks) periods (Table 1). All diets were formulated to meet nutrient requirements established by the NRC [13] (1994). The birds were housed in floor and routinely managed as any other commercial broiler flock.

\subsection{Growth Performance}

Feed intake (FI) and body weight were measured in the $3^{\text {rd }}, 5^{\text {th }}$ and $6^{\text {th }}$ weeks to monitor the average daily gain (ADG), average daily FI and gain/feed (G/F) ratio.

\subsection{Blood Lipids}

At the end of $3^{\text {rd }}, 5^{\text {th }}$ and $6^{\text {th }}$ weeks, three birds were randomly chosen from each replicate and bled via wing vein puncture to obtain blood samples. Serum samples from blood were separated by low-speed centrifugation $\left(1500 \mathrm{~g}\right.$ for $15 \mathrm{~min}$ at $\left.20^{\circ} \mathrm{C}\right)$. Commercially available kits (Sigma Diagnostics, Taufkirchen, Germany) were used to analyse the serum for COL, TG and HDL on an autoanalyzer. LDL levels were estimated using the Friedewald equation [14]. Values were expressed as $\mathrm{mg} / \mathrm{dL}$.

\subsection{Carcass Characteristics}

At the end of the experiment, three birds were selected from each replicate. Feed was withdrawn $12 \mathrm{~h}$ before slaughter. Birds were defeathered and eviscerated after slaughtering by bleeding the jugular vein. The gizzard, heart, liver, small intestine, cecum and abdominal fat were excised and weighed and their relative weights to live BW (\%) were calculated. Then, after removal of head, shanks and offal, ready to cook carcass was obtained. The ready to cook carcass weight was then determined, and the carcass yield percentage (dressing percentage) was calculated by dividing the ready to cook

Table 1. Composition of the experimental starter and finisher diets fed to broilers (as fed basis).

\begin{tabular}{|c|c|c|c|c|c|c|}
\hline & & Starter & & & Finisher & \\
\hline Diet & Control & $0.2 \mathrm{GP}$ & $0.4 \mathrm{GP}$ & Control & $0.2 \mathrm{GP}$ & $0.4 \mathrm{GP}$ \\
\hline Corn & 56 & 56 & 56 & 57 & 56.8 & 56.6 \\
\hline Soybean meal & 37.5 & 37.3 & 37.1 & 32 & 32 & 32 \\
\hline Salt & 1 & 1 & 1 & 1 & 1 & 1 \\
\hline Methionine + lysine & 0.2 & 0.2 & 0.2 & 0.2 & 0.2 & 0.2 \\
\hline Oil & 3 & 3 & 3 & 5.4 & 5.4 & 5.4 \\
\hline Limestone & 1 & 1 & 1 & 1.86 & 1.86 & 1.86 \\
\hline Di-calcium Phosphate & 0.75 & 0.75 & 0.75 & 1.37 & 1.37 & 1.37 \\
\hline $\operatorname{Premix}^{1}$ & 0.75 & 0.75 & 0.75 & 1.37 & 1.37 & 1.37 \\
\hline $\mathrm{GP}^{2}$ & 0 & 0.2 & 0.4 & 0 & 0.2 & 0.4 \\
\hline Crude protein & 22 & 22.1 & 21.9 & 19.48 & 19.48 & 19.48 \\
\hline Crude fiber & 4.25 & 4.25 & 4.25 & 3.88 & 3.88 & 3.88 \\
\hline Crude fat & 5.46 & 5.46 & 5.46 & 7.93 & 7.93 & 7.93 \\
\hline Ash & 5.04 & 5.04 & 5.04 & 4.87 & 4.87 & 4.87 \\
\hline Calcium & 0.77 & 0.77 & 0.77 & 1.29 & 1.3 & 1.3 \\
\hline Phosphorous & 0.4 & 0.4 & 0.4 & 0.5 & 0.48 & 0.49 \\
\hline $\mathrm{ME}, \mathrm{kcal} / \mathrm{kg}$ & 2800 & 2850 & 2830 & 3000 & 3050 & 3030 \\
\hline
\end{tabular}

${ }^{1}$ Vitamin premix/kg diet: vitamin A-12,000 IU; vitamin $\mathrm{D}_{3}-1500 \mathrm{IU}$; vitamin E-50 mg; vitamin $\mathrm{K}_{3}-5 \mathrm{mg}$; vitamin $\mathrm{B}_{1}-3 \mathrm{mg}$; vitamin $\mathrm{B}_{2}-6 \mathrm{mg}$; vitamin $\mathrm{B}_{6}-5 \mathrm{mg}$; vitamin $\mathrm{B}_{12}-0.03 \mathrm{mg}$; niacin $-25 \mathrm{mg}$; Ca-D-pantothenate $-12 \mathrm{mg}$; folic acid $-1 \mathrm{mg}$; D-biotin-0.05 mg; apo-carotenoic acid ester-2.5 mg; choline chloride $-400 \mathrm{mg} ;{ }^{2}$ The chemical analysis of GP (\%): Energy (cal/100 g), 332; protein, 16.8; moisture, 5.61; fat, 0.76; total ash, 3.18 . 
weight by the live BW of birds multiplied by 100 . Weights of breast thigh, back, wing and neck were recorded.

\subsection{Digestion Trial}

At day 35 post feeding 3 birds from each replicate of the experimental groups were used in a total feed and feces collection trial. Birds were housed individually and fed their experimental rations. A six days total collection of feed and feces period was performed after an adaptation period of 3 days. Digestibility of DM, CP and EE was determined.

\subsection{Chemical Analysis}

GP used in the experiment was obtained from a market from a commercial brand with the purity of $100 \%$. It was analyzed for moisture and ash, feed and feces were analyzed for DM, CP, and EE according to the methods of the Association of Official Analytical Chemists [15]. DM was determined by drying at $105^{\circ} \mathrm{C}$ until constant weight. Nitrogen was determined by Kjeldahl method $(\mathrm{CP}=\mathrm{N} \times$ $6.25)$.

\subsection{Statistical Analysis}

Statistical analyses were conducted using the SPSS for Windows statistical package program, (version 18) to determine if variables differed between groups. Significant effects were further explored using Duncan's multiple range tests to ascertain differences among treatment means. A significance level of $\mathrm{P}<0.05$ was used.

\section{RESULTS}

\subsection{Growth Performance}

Both levels of GP had no effect on feed intake of broilers during the first three weeks of the feeding trial (Table 2). This trend was maintained until the termination of the feeding trial at day 42 (Table 2). Similar effects of GP were observed on body weight gain and F/G ratio at different periods post feeding. Birds fed the control diet had similar weight gain and $\mathrm{F} / \mathrm{G}$ ratios compared to broilers fed the two levels of GP (Table 2).

\subsection{The Blood Lipids}

The mean of total COL, TG, LDL and HDL in birds of different groups is presented in Table 3.

\section{3. $\mathrm{COL}$}

It showed a significant $(\mathrm{P}<0.05)$ decrease in the level of COL in both levels of GP ( 98 and $90 \mathrm{mg} / \mathrm{dL})$ in comparison to the control $(149 \mathrm{mg} / \mathrm{dL})$ at third week post
Table 2. Effect of garlic powder (GP) on performance of broilers (1 to $42 \mathrm{~d}), \mathrm{g}^{1}$.

\begin{tabular}{cccccc}
\hline diet & Period & Control & $0.2 \mathrm{G}$ & $0.4 \mathrm{G}$ & P value \\
\hline Body weight & $21 \mathrm{~d}$ & 533 & 570 & 614 & 0.20 \\
& $35 \mathrm{~d}$ & 1689 & 1780 & 1768 & 0.18 \\
& $42 \mathrm{~d}$ & 2050 & 2079 & 2099 & 0.11 \\
Weight gain & $21 \mathrm{~d}$ & 486 & 523 & 567 & 0.15 \\
& $35 \mathrm{~d}$ & 1642 & 1733 & 1721 & 0.23 \\
& $42 \mathrm{~d}$ & 2003 & 2032 & 2052 & 0.21 \\
Feed intake & $21 \mathrm{~d}$ & 693 & 752 & 798 & 0.33 \\
& $35 \mathrm{~d}$ & 2787 & 2990 & 2953 & 0.20 \\
& $42 \mathrm{~d}$ & 3690 & 3740 & 3736 & 0.21 \\
Feed: gain (g: g) & $21 \mathrm{~d}$ & 1.3 & 1.3 & 1.3 & 0.50 \\
& $35 \mathrm{~d}$ & 1.65 & 1.68 & 1.67 & 0.32 \\
& $42 \mathrm{~d}$ & 1.8 & 1.79 & 1.78 & 0.12 \\
\hline
\end{tabular}

${ }^{1}$ Means represent 90 chicks per treatment.

Table 3. Effect of garlic powder (GP) on blood lipid parameters $(\mathrm{mg} / \mathrm{dL})$ of broilers ${ }^{1,2}$.

\begin{tabular}{|c|c|c|c|c|c|}
\hline Parameter & Weeks post treatment & Control & $0.2 \mathrm{G}$ & $0.4 \mathrm{G}$ & $P$ value \\
\hline \multirow[t]{4}{*}{ TG } & 3 & $210.9^{\mathrm{a}}$ & $49.2^{\mathrm{b}}$ & $59.4^{\mathrm{b}}$ & 0.05 \\
\hline & 5 & $214.0^{\mathrm{a}}$ & $51.4^{\mathrm{b}}$ & $53.7^{\mathrm{b}}$ & 0.05 \\
\hline & 6 & $217.0^{\mathrm{a}}$ & $53.6^{\mathrm{b}}$ & $55.0^{\mathrm{b}}$ & 0.05 \\
\hline & Average & $213.9^{\mathrm{a}}$ & $51.4^{\mathrm{b}}$ & $56.0^{\mathrm{b}}$ & 0.05 \\
\hline \multirow[t]{4}{*}{$\mathrm{COL}$} & 3 & $149.1^{\mathrm{a}}$ & $98^{\mathrm{b}}$ & $90^{\mathrm{b}}$ & 0.05 \\
\hline & 5 & $152.0^{\mathrm{a}}$ & $100.4^{\mathrm{b}}$ & $91.0^{\mathrm{b}}$ & 0.05 \\
\hline & 6 & $154.0^{\mathrm{a}}$ & $102.3^{\mathrm{b}}$ & $93.0^{\mathrm{b}}$ & 0.05 \\
\hline & Average & $151.7^{\mathrm{a}}$ & $100.2^{\mathrm{b}}$ & $91.3^{\mathrm{b}}$ & 0.05 \\
\hline \multirow[t]{4}{*}{$\mathrm{HDL}$} & 3 & $68.1^{\mathrm{b}}$ & $85.8^{\mathrm{a}}$ & $88.7^{\mathrm{a}}$ & 0.05 \\
\hline & 5 & $69.9^{\mathrm{b}}$ & $88.0^{\mathrm{a}}$ & $90.3^{\mathrm{a}}$ & 0.05 \\
\hline & 6 & $71.7^{\mathrm{b}}$ & $90.1^{\mathrm{a}}$ & $91.2^{\mathrm{a}}$ & 0.05 \\
\hline & Average & $69.9^{\mathrm{b}}$ & $88.0^{\mathrm{a}}$ & $90.0^{\mathrm{a}}$ & 0.05 \\
\hline \multirow[t]{4}{*}{ LDL } & 3 & $187.0^{\mathrm{a}}$ & $110.0^{\mathrm{b}}$ & $112.0^{\mathrm{b}}$ & 0.05 \\
\hline & 5 & $191.0^{\mathrm{a}}$ & $113.0^{\mathrm{b}}$ & $112.4^{\mathrm{b}}$ & 0.05 \\
\hline & 6 & $194.0^{\mathrm{a}}$ & $116.9^{\mathrm{b}}$ & $113.9^{\mathrm{b}}$ & 0.05 \\
\hline & Average & $190.7^{\mathrm{a}}$ & $113.3^{\mathrm{b}}$ & $112.7^{\mathrm{b}}$ & 0.05 \\
\hline
\end{tabular}

${ }^{1}$ Means within the same row with different common superscripts differ $(\mathrm{P}<$ $0.05){ }^{2}$ Means represent 18 chicks per treatment.

treatment. On $5^{\text {th }}$ week post treatment there was significant $(\mathrm{P}<0.05)$ decrease in total COL concentration in GP treatments $(100.4$ and $91.0 \mathrm{mg} / \mathrm{dL})$ as compared to control $(152.0 \mathrm{mg} / \mathrm{dL})$. Also, on sixth week of post treatment there was a significant $(\mathrm{P}<0.05)$ decrease in total COL concentration in birds fed GP (102.3 and 93.0 $\mathrm{mg} / \mathrm{dL})$ as compared to control birds $(154.0 \mathrm{mg} / \mathrm{dL})$. When data (i.e., $3^{\text {rd }}, 5^{\text {th }}$ and $6^{\text {th }}$ weeks) was pooled, it showed a significant $(\mathrm{P}<0.05)$ decrease in total $\mathrm{COL}$ 
level in birds fed garlic (100.2 and $91.3 \mathrm{mg} / \mathrm{dL})$ in comparison to birds fed no GP (151.7 mg/dL). Garlic supplementation inhibited the increase in COL level with advancement of age.

\subsection{TG}

There was a significant $(\mathrm{P}<0.05)$ decrease in the level of TG in birds of GP groups (49.2 and $59.4 \mathrm{mg} / \mathrm{dL}$ ) in comparison to control birds $(210.9 \mathrm{mg} / \mathrm{dL})$ at three weeks of treatment (Table 3). On $5^{\text {th }}$ week of post treatment there was a significant $(\mathrm{P}<0.05)$ decrease in $\mathrm{TG}$ concentration in GP birds ( 51.4 and $53.7 \mathrm{mg} / \mathrm{dL}$ ) as compared to control birds $(214.0 \mathrm{mg} / \mathrm{dL})$. On $6^{\text {th }}$ week of post treatment there was a significant $(\mathrm{P}<0.05)$ decrease in TG concentration associated with feeding GP (53.6 and $55.0 \mathrm{mg} / \mathrm{dL})$ as compared to control $(217.0 \mathrm{mg} / \mathrm{dL})$. When data (i.e., $3^{\text {rd }}, 5^{\text {th }}$ and $6^{\text {th }}$ weeks) were pooled, it showed a significant $(\mathrm{P}<0.05)$ decrease in GP groups (51.4 and $56.0 \mathrm{mg} / \mathrm{dL}$ ) in comparison to control group (213.9 mg/dL).

\subsection{LDL}

It showed a significant $(\mathrm{P}<0.05)$ decrease in the level of LDL in birds fed the two levels of GP (110 and 112 $\mathrm{mg} / \mathrm{dL})$ in comparison to the control birds $(187 \mathrm{mg} / \mathrm{dL})$ at three weeks post treatment (Table 3). On $5^{\text {th }}$ week of post treatment there was a significant $(\mathrm{P}<0.05)$ decrease in LDL concentration in GP groups (113.0 and 112.4 $\mathrm{mg} / \mathrm{dL})$ as compared to control $(191.0 \mathrm{mg} / \mathrm{dL})$. Also, on $6^{\text {th }}$ week of post treatment there was a significant $(\mathrm{P}<$ 0.05) decrease in LDL concentration in both GP groups (116.9 and $113.9 \mathrm{mg} / \mathrm{dL}$ ) as compared to control (194.0 $\mathrm{mg} / \mathrm{dL}$ ). When data (i.e., $3^{\text {rd }}, 5^{\text {th }}$ and $6^{\text {th }}$ weeks) was pooled, it showed a significant $(\mathrm{P}<0.05)$ decrease in GP groups (113.3 and $112.7 \mathrm{mg} / \mathrm{dL})$ in comparison to control group (190.7 mg/dL).

\subsection{HDL}

Results of this research showed a significant $(\mathrm{P}<0.05)$ increase in the level of HDL in birds fed the two levels of GP $(85.8$ and $88.7 \mathrm{mg} / \mathrm{dl})$ in comparison to the control birds $(68.1 \mathrm{mg} / \mathrm{dl})$ at three weeks post treatment (Table 3). On $5^{\text {th }}$ week of post treatment there was a significant $(\mathrm{P}<0.05)$ increase in HDL concentration in GP groups (88.0 and $90.3 \mathrm{mg} / \mathrm{dL}$ ) as compared to control (69.9 $\mathrm{mg} / \mathrm{dL})$. Also, on $6^{\text {th }}$ week of post treatment there was a significant $(\mathrm{P}<0.05)$ increase in HDL concentration in both GP groups (90.1 and $91.2 \mathrm{mg} / \mathrm{dL})$ as compared to control $(71.7 \mathrm{mg} / \mathrm{dL})$. When data (i.e., $3^{\text {rd }}, 5^{\text {th }}$ and $6^{\text {th }}$ weeks) was pooled, it showed a significant $(\mathrm{P}<0.05)$ increase in GP groups ( 88.0 and $90.0 \mathrm{mg} / \mathrm{dL})$ in comparison to control group $(69.9 \mathrm{mg} / \mathrm{dL})$.

\subsection{Carcass Cuts}

Relative weights (\%) of the carcass cuts and digestive organs investigated were not affected by GP (Table 4). Similar effect of GP in the dressing percentages and abdominal fat weight was observed.

\subsection{Digestibility}

The digestibility of total tract DM, CP and EE digestibility were improved $(\mathrm{P}<0.05)$ by the addition of the garlic powder compared to that in the control diet (Table 5).

\section{DISCUSSION}

\subsection{Weight Gain}

The lack of GP effects on broilers feed intake, weight

Table 4. Effect of garlic powder (GP) on relative weights (\%) of selected digestive organs of broilers ${ }^{1}$.

\begin{tabular}{|c|c|c|c|c|}
\hline & control & $0.2 \mathrm{G}$ & $0.4 \mathrm{G}$ & $P$ value \\
\hline Live wt & 2050 & 2079 & 2099 & 0.21 \\
\hline Carcass wt & 1466 & 1486 & 1488 & 0.09 \\
\hline $\mathrm{D} \%$ & 70.5 & 70.5 & 70.9 & 0.08 \\
\hline Abdomen fat & 1.91 & 1.90 & 1.89 & 0.11 \\
\hline Head & 2.1 & 2 & 2 & 0.08 \\
\hline Neck & 5 & 4.7 & 5.3 & 0.21 \\
\hline Wing & 7.3 & 7.3 & 7.0 & 0.12 \\
\hline Back & 14.6 & 15.0 & 18.7 & 0.23 \\
\hline Thigh & 17.7 & 20.0 & 19.0 & 0.22 \\
\hline Breast & 20.0 & 21.6 & 21.3 & 0.30 \\
\hline Heart & 0.8 & 0.7 & 0.8 & 0.23 \\
\hline Liver & 2.7 & 3.0 & 2.3 & 0.11 \\
\hline Gizzard & 3.7 & 3.0 & 3.3 & 0.09 \\
\hline Feet & 4.0 & 4.3 & 3.7 & 0.10 \\
\hline Cecum & 1.0 & 0.9 & 1.3 & 0.22 \\
\hline Small intestine weight & 4.3 & 4.7 & 5.3 & 0.15 \\
\hline Small intestine length & 165 & 160 & 170 & 0.21 \\
\hline Cecum length & 19 & 20 & 21 & 0.20 \\
\hline
\end{tabular}

${ }^{1}$ Means represent 18 chicks per treatment.

Table 5. Effect of garlic powder (GP) on the whole tract apparent digestibility of the diets of broilers.

\begin{tabular}{ccccc}
\hline & DM & CP & EE & P value \\
\hline Control $^{1}$ & $71.0^{\mathrm{b}}$ & $55.2^{\mathrm{b}}$ & $86.0^{\mathrm{b}}$ & 0.05 \\
$0.2 \mathrm{G}$ & $74.1^{\mathrm{a}}$ & $60.0^{\mathrm{a}}$ & $90.1^{\mathrm{a}}$ & 0.05 \\
$0.4 \mathrm{G}$ & $74.4^{\mathrm{a}}$ & $60.2^{\mathrm{a}}$ & $90.4^{\mathrm{a}}$ & 0.05 \\
\hline
\end{tabular}

${ }^{\mathrm{a}, \mathrm{b}}$ Mean values within a column having different superscripts are significantly different by least significant difference test $(\mathrm{P}<0.05) ;{ }^{1}$ Means represent 18 chicks per treatment. 
gain and feed conversion ratio observed in this study is in agreement with previous observations that indicated that herbs, plant extracts, essential oil and/or the main components of the essential oil that did not affect body weight gain, feed intake or feed efficiency in broilers [6, 10,16-22]. Lewis et al. (2003) [7] showed that addition of plant extracts to broilers' diet has some effects on performance and microbial activity of intestinal tract but, none of them were significant. The absence of garlic on feed intake and then general performance was probably due to the intense smell of garlic, which required a period of adaptation of chickens to this kind of feed [11].

\subsection{Blood Lipids}

\subsection{1. $\mathrm{COL}$}

All of the blood lipid metabolites (COL, TG, LDL and HDL) tested were significantly improved by GP supplementation. These results agree with previous reports where dietary supplementation of GP at both concentrations (i.e., $1.5 \%$ and $3.0 \%$ ) was found to cause a significant decrease in the mean values of total COL as compared to control broilers. Prasad et al. 2009 [23] reported similar findings were total cholesterol, triglycerides, LDL and VLDL were significantly decreased, while HDL was significantly increased by garlic supplementation in chicken up to 8 weeks of age in comparison to control group. This may probably be due to the possible mechanism of hypocholesterolaemic and hypolipidemic action of garlic products which depresses the hepatic activities of lipogenic and cholesterogenic enzymes such as malic enzyme, fatty acid synthase, glucose-6-phosphatase dehydrogenase [3,24] and 3-hydroxyl-3-methyl-glutaryl-CoA (HMG-CoA) reductase [25]. Afzal et al. (1985) [26] reported that polyunsaturated fatty acids prevent atherosclerosis through the formation of cholesterol esters. They further reported the presence of higher polyunsaturated fatty acids like arachidonate and eicosapentenoate in garlic which could well be responsible for preventing atherosclerosis. However, higher levels of GP (4.5\%) showed no significant difference in mean values of plasma total COL. Similar findings were reported in rats where garlic powder failed to influence the lipid profiles in rats [27]. Furthermore, GP can facilitate activity of enzymes which are involved in the conversion of cholesterol to bilious acids and subsequently, there will be less cholesterol in the carcass $[28,29]$.

\subsubsection{TG}

Results of the study showed that GP significantly decreased the levels of TG. Both levels of GP decreased TG levels compared to TG levels in birds of the control group. This effect can be explained by the possible inhibition of the Acetyl CoA synthetase enzyme that is nec- essary for the biosynthesis of fatty acids [3,24]. Eidi et al. (2006) [30] reported that garlic extract significantly decreased total cholesterol, triglycerides in diabetic rats.

\subsubsection{LDL}

Both levels of GP decreased LDL levels compared to the levels in birds of the control group. This effect can be explained by the possible mechanism of antioxidant and antiperoxide lowering action of GP (S-allyl cysteine sulfoxide) on LDL or the decrease in hepatic production of VLDL which serves as the precursor of LDL in the blood circulation [29].

\subsubsection{HDL}

The significant effect of GP on the mean values of HDL compared to control can be explained by the mechanism hypocholesterolaemic and the hypolipidemic action of GP. The compound allicin combines with the -SH group that is important in activation of $\mathrm{CoA}$ which is essential for the biosynthesis of cholesterol. Results of this study indicate the significant increase of HDL by feeding GP, however, reports on the effects of GP on HDL in different species are inconsistent $[3,24]$.

\subsection{Digestive Organs and Carcass Cuts}

Relative weights of liver, gizzard and heart were not affected by GP. The lack of GP effect on broilers visceral organs observed in this experiment is similar to that reported by previous research. Raeesi et al. (2010) [31] reported garlic at levels of $1 \%$ and $3 \%$ had no significant effects on relative weights of carcass, fat pad, or digestive organs among different treatments except for the small intestine. Similar trend was observed for small intestine and cecum relative weights. These findings are in agreement with the findings of Hashish et al. (1995) [32] and Ceylan et al. [33] (1998).

Results of this study showed that all carcass cuts (thigh, breast, back and neck) were the same in broilers of control GP groups. This result is in disagreement with previous research where supplementation of $1 \%$ GP caused higher thigh yield while the poorest thigh yield belonged to $3 \%$ GP group. Groups received $1 \%$ garlic powder significantly had higher breast yield than others [31].

\subsection{Digestibility}

The apparent digestibility of total tract DM, CP and EE was improved $(\mathrm{P}<0.05)$ by the addition of the GP compared to that in the control diet. These findings are in agreement with previous research of Hernandes et al. (2004) [18] who showed that plant extract supplementation improved apparent whole tract digestibility of the nutrients. 
The improvement of total tract digestibility in broilers fed different levels of GP was probably due to herbal effects in increasing the microbial population especially the number of bacteria such as E. coli, Clostridium spp. and Enterococci. The efficacy of any dietary feed additives observed under less hygienic housing conditions, especially under the separate floor pens equipped with wood shaving litter stimulates the activity of the feed additives. The isoprene derivatives, flavonoids, glucosinolates and other plant metabolites may affect the physiological and chemical function of the digestive tract. The stabilizing effect on intestinal microflora may be associated with intermediate nutrient metabolism [11,34,35]. The active principles of essential oils act as a digestibility enhancer, balancing the gut microbial ecosystem and stimulating the secretion of endogenous digestive enzymes and thus improving growth performance in poultry [36-38].

\section{ACKNOWLEDGEMENTS}

The authors gratefully acknowledge the support of An Najah National University, and the efforts of Dr. H. Abu Qaoud from the faculty of agriculture.

\section{REFERENCES}

[1] Iji, P.A., Saki, A. and Tivey, D.R. (2001) Body and intestinal growth of broiler chicks on a commercial starter diet. 1. Intestinal weight and mucosal development. British Poultry Science, 42, 505-513. doi:10.1080/00071660120073151

[2] CAFA (Commission on Antimicrobial Feed Additives) (1997) Antimicrobial feed additives. Swedish Official Government Reports 132, Ministry of Agriculture, Stockholm.

[3] Qureshi, A.A., Abuirmeileh, N., Din, Z.Z., Elson, C.E. and Burger, W.C. (1983) Inhibition of cholesterol and fatty acid biosynthesis in liver enzymes and chicken hepatocytes by polar fractions of garlic. Lipids, 18, 343348. doi:10.1007/BF02537229

[4] Cavallito, C.J., Buck, J.S. and Suter, C.M. (1994) Allicin, the antibacterial principle of Allium sativum. Determination of the chemical composition. Journal of the American Chemical Society, 60, 1952-1958.

[5] Tollba, A.A.H. and Hassan, M.S.H. (2003) Using some natural additives to improve physiological and productive performance of broiler chicks under high temperature conditions. Black cumin (niglla sativa) or Garlic (allium sativum). Poultry Science, 23, 327-340.

[6] Demir, E., Sarica, S., Ozcan M.A. and Suicmez, M. (2003) The use of natural feed additives as alternatives for an antibiotic growth promoter in broiler diets. British Poultry Science, 44, S44-S45. doi:10.1080/00071660301944

[7] Lewis, M.R., Rose, S.P., Mackenzie, A.M. and Tucker, L.A. (2003) Effects of dietary inclusion of plant extracts on the growth performance of male broiler chickens. British Poultry Science, 44, S43-S44.

[8] Sivam, G.P. (2001) Protection against helicobacter pylori and other bacterial infections by garlic. Journal of Nutrition, 131, 1106S-1108S.

[9] Amagase, H., Petesch, B.L., Matsuura, H., Kasuga, S. and Itakura, Y. (2001) Intake of garlic and its bioactive components. Journal of Nutrition, 131, 955S-962S.

[10] Konjufca, V.H., Pesti, G.M. and Bakalli, R.I. (1997) Modulation of cholesterol levels in broiler meat by dietary garlic and copper. Poultry Science, 76, 1264-1271.

[11] Horton, G.M.J., Fennell, M.J. and Prasad, B.M. (1991) Effects of dietary garlic (Allium sativum) on performance, carcass composition and blood chemistry changes in broiler chickens. Canadian Journal of Animal Science, 71, 939-942. doi:10.4141/cjas91-113

[12] Chowdhury, S.R., Chowdhury, S.D. and Smith, T.K. (2002) Effects of dietary garlic on cholesterol metabolism in laying hens. Poultry Science, 81, 1856-1862.

[13] National Research Council (NRC) (1994) Nutrient requirements of poultry. 9th Edition, National Academy Press, Washington DC.

[14] Friedewald, W.T., Levy, R.I. and Fredrickson, D.S. (1972) Estimation of concentration of low-density lipoprotein cholesterol in plasma without use of the ultracentrifuge. Clinical Chemistry, 18, 449-502.

[15] AOAC (1990) Official methods of analysis. 15th Edition, Association of Official Analytical Chemists, Washington DC.

[16] Cross, D.E., Acamovic, T., Deans, S.G. and McDevitt, R.M. (2002) The effect of dietary inclusion of herbs and their volatile oils on the performance of growing chickens. British Poultry Science, 43, 533-535.

[17] Botsoglou, N.A., Christaki, E., Florou-Paneri, P., Giannenas, I., Papageorgiou, G., and Spais, A.B. (2004) The effectof a mixture of herbal essential oils or $\alpha$-tocopheryl acetate on performance parameters and oxidation of body lipid in broilers. South African Journal of Animal Science, 34, 52-61. doi:10.4314/sajas.v34i1.4039

[18] Hernandez, F., Madrid, J., Garcia, V., Orengo, J. and Megías, M.D. (2004) Influence of two plant extracts on broilers performance, digestibility, and digestive organ size. Poultry Science, 83, 169-174.

[19] Bampidis, V.A., Christodoulou, V., Florou-Paneri, P., Christaki, E., Chatzopoulou, P.S., Tsiligianni, T. and Spais, A.B. (2005) Effect of dietary dried oregano leaves on growth performance, carcase characteristics and serum cholesterol of female early maturing turkeys. British Poultry Science, 46, 595-601. doi:10.1080/00071660500256057

[20] Sarica, S., Ciftci, A., Demir, E., Kilinc, K. and Yildirim, Y. (2005) Use of an antibiotic growth promoter and two herbal natural feed additives with and without exogenous enzymes in wheat based broiler diets. South African Journal of Animal Science, 35, 61-72.

[21] Amooz Mehr, A. and Dastar, B. (2009) Effects of alcoholic extract of two herbs (garlic and thymus) on the performance and blood lipids of broiler chickens. Journal of 
Agricultural Sciences and Natural Resources, 16, 61-72.

[22] Freitas, R., Fonseca, J.B., Soares, R.T., Rostagno, H.S. and Soares, P.R. (2001) Utilization of garlic (Allium sativum L.) as growth promoter of broilers. Revista Brasileira de Zootecnia, 30, 761-765.

[23] Prasad, R., Rose, M.K., Vermani, M., Garg, S.L. and Puri, J.P. (2009) Lipid profile of chicken (Gallus domesticus) in response to dietary supplementation of garlic (Allium sativum). International Journal of Poultry Science, 8, 270-276. doi:10.3923/ijps.2009.270.276

[24] Chi, M.S., Koh, H. and Steward, T.J. (1982) Effects of garlic on lipid metabolism in rats fed cholesterol or lard. Journal of Nutrition, 112, 241-248.

[25] Qureshi, A.A., Abuirmeileh, N., Din, Z.Z., Ahmad, Y., Elson, C.E. and Burger, W.C. (1983) Suppression of avian hepatic lipid metabolism by solvent extracts of garlic: Impact on serum lipids. Journal of Nutrition, 113, 1746-1755.

[26] Afzal, M., Hassan, R.A.H., El-kazini, A.A. and Fattah, R.M.A. (1985) Allium sativum in the control of atherosclerosis. Agricultural and Biological Chemistry, 49, 1187-1188. doi:10.1271/bbb1961.49.1187

[27] Islam, M.S. and Choi, H. (2008) Comparative effects of dietary ginger (Zingiber officinale) and garlic (Allium sativum) investigated in a type 2 diabetes model of rats. Journal of Medicinal Food, 11, 152-159. doi:10.1089/jmf.2007.634

[28] Bordia, A., Bansol, H.C., Arora, S.K. and Singal, S.V. (1975) Effect of the essential oils of garlic and onion on dementary hyperlipemia. Atherosterosis, 2, 15-18. doi:10.1016/0021-9150(75)90091-X

[29] Kim, Y.J., Jin, S.K. and Yang, H.S. (2009) Effect of dietary garlic bulb and husk on the physicochemical properties of chicken meat. Poultry Science, 88, 398-405. doi:10.3382/ps.2008-00179

[30] Eidi, A., Eidi, M. and Esmaeili, E. (2006) Antidiabetic effect of garlic (Allium sativum L.) in normal or streptozotocin-induced diabetic rats. Phytomedicine, 9, 624-629. doi:10.1016/j.phymed.2005.09.010
[31] Raeesi, M., Hoeini-Aliabad, S.A., Roofchaee, A., Zare Shahneh, A. and Pirali, S. (2010) Effect of periodically use of garlic (Allium sativum) power on performance and carcass characteristics in droiler chickens. World Academy of Science, Engineering and Technology, 68, 12131219.

[32] Hashish, S.M., El-Ghamry, A. and Ibrahim, S.A. (1995) The effect of using kemzyme, zinc bacitracin, lysoforte and fermacto on carcass and meat quality in broiler chicks. Proceedings of the 10th European Symposium on Poultry Nutrition, Antalya, 15-19 October 1995, 403-404.

[33] Ceylan, N., Gunal, M. andCaliskaner, S. (1998) Effect of enzyme and antibiotic supplementation on growth performance and ileal parameters in broilers fed rye diets. UNL Poultry Reports. http://ianrpubs.unl.edu/poultry/mp70/mp70-14.htm

[34] Bratta, M.T., Deans, S.G., Biondi, D.M. and Ruberto, G. (1998) Chemical composition antimicrobial and antioxidative activity of laurel, Sage, Rosemary, Oregano and Coriander Essentials Oils. Journal of Essential Oil Research, 10, 618-627.

[35] Jamroz, D., Orda, J., Kamel, C., Wilicziewicz, A., Wertelecki, T. and Skorupinska, J. (2003) The influence of phytogenic extracts on performance, nutrient digestibility, carcass characteristics, and gut microbial status in broiler chickens. Journal of Animal and Feed Sciences, 12, 583-596.

[36] Lovkova, M.Y., Buzuk, G.N., Sokolova, S.M. and Kliment'eva, N.I. (2001) Chemical features of medicinal plants (a review). Applied Biochemistry and Microbiology, 37, 229-237. doi:10.1023/A:1010254131166

[37] Williams P. and Losa, R. (2001) The use of essential oils and their compounds in poultry nutrition. World's Poultry, 17, 14-15.

[38] Cross, D.E., McDevitt, R.M., Hillman, K. and Acamovic, T. (2007) The effect of herbs and their associated essential oils on performance, dietary digestibility and gut microflora in chickens from 7 to 28 days of age. British Poultry Science, 48, 496-506. doi:10.1080/00071660701463221 